\title{
FUNGI AND MINERALS OCCURRING IN HEARTWOOD DISCOLORATIONS IN QUERCUS ROBUR TREES
}

\author{
KRYSTYNA PRZYBYE \\ Polish Academy of Sciences, Institute of Dendrology \\ Parkowa 5, 62-035, Kórnik, Poland \\ e-mail:kmtprz@man.poznan.pl
}

(Received: May 22, 2006. Accepted: July 17, 2006)

\begin{abstract}
The studied Quercus robur trees were oaks protected as monuments of nature (200-350 years old) and oaks growing in forest stands (200-300 years old). The most visible symptoms occurring in aboveground organs included defoliation (25-75\%), dying of twigs and branches. Discoloured heartwood, obtained with an 80-cm Pressler borer, differed in colour intensity from normal wood and was divided into two groups: stained brown and dark brown. The brown-stained heartwood was a more active site, considering the number of fungi and their ability to produce enzymes (phenoloxidase, pectinase and cellulase) in comparison with the dark-brown-stained heartwood. This brown-stained heartwood contained also statistically more $\mathrm{Ca}, \mathrm{Mg}$ and $\mathrm{Mn}$.
\end{abstract}

KEY WORDS: pedunculate oak, trunk heartwood, fungi, enzymes, minerals.

\section{INTRODUCTION}

Discoloration and decay of wood are serious defects of timber trees. The development of the discoloration begins with an injury of the tree, e.g. dying or breaking off of branches, attack of insects or other factors, e.g. exposure to outdoor weathering and artificial (UV) light (e.g. Shigo 1972; Shortle and Cowling 1978; Hon and Feist 1986; Grosclaude 1993; Lilja and Heikkilä 1995; Dujesiefken et al. 1998). Discoloration originating as a result of tree response to injuries are colonized by nonhymenomycetous fungi and bacteria (e.g. Tattar et al. 1971; Hallaksela and Niemistö 1998). Decay fungi inhabited tissues earlier changed by those microorganisms, which are able to detoxify the phenolic substances (Shortle and Cowling 1978; Rayner and Boddy 1988; Grosclaude 1993). Fungi most often isolated from discoloured wood of trees e.g. of birch, maple, yellow-poplar, sweetgum and white oak belong to the genera Phialophora, Epicoccum, Gliomastix, Fusarium, Coniothyrium, Nodulisporium, Ophiostoma, Alternaria, Trichocladium and Cladosporium (Shortle and Cowling 1978; Shortle 1979; Arnold and Gramss 1992; Przybył 2001).

An increase in inorganic components in discoloured sapwood was reported by many workers. The proportion of inorganic material is higher in discoloured and decayed wood than in normal wood (Shigo and Sharon 1970; Shigo and Hillis 1973; Przybył and Mańka 2000), although its content depends on wood structure (Penninckx et al. 2001). Some studies indicate that mean nitrogen content varied among decayed wood samples but was always higher in decayed wood than in normal wood (Fukasawa et al. 2005). Many investigations on wood discoloration of relatively young trees without and with heartwood (e.g. $Q$. rubra and $Q$. alba), i.e. 20-50 years old, contrast with the rare knowledge about old trees over 200 years old. Poland is one of the few countries in Europe where large numbers old oak stands and monumental trees have survived (Kasprzak 2001). My observations of the condition of old forest stands and monumental trees made in the last three years prompted me to study wood discoloration.

The purpose of this investigation was to identify the fungi occurring in discoloured heartwood of old specimens of pedunculate oak $(Q$. robur) and the possible effects of those fungi on the heartwood by analysing: (1) phenoloxidase (laccase), which is involved in detoxification of phenols, and (2) enzymes that can participate in decomposition of pectin and cellulose. Moreover, mineral concentrations in discoloured and normal wood were also investigated and compared in relation to intensity of discoloration.

\section{MATERIAL AND METHODS}

\section{Plant material and wood collection}

The studied trees of Quercus robur were grown on sites belonging to 19 Forest Districts. Among these trees, 12 oaks protected as monuments of nature were 200-350 years old and 21 oaks growing in forest stands were 200-300 ye- 
ars old (Ufnalski, in preparation). The most visible symptoms occurring in aboveground organs included defoliation (25-75\%), and dying of twigs and branches. Moreover, the following types of wounds were observed on the trees: broken branches, broken tops, branch wounds and wounds resembling frost cracks.

Samples of stem wood were obtained with an $80-\mathrm{cm}$ Pressler borer $1.3 \mathrm{~m}$ above ground. These samples comprised mostly heartwood; the sapwood was composed of only 5-20 youngest annual rings (Ufnalski, in preparation). Discolorations of heartwood (starting most often from pith) were observed on $80 \%$ of studied trees. Discoloured heartwood differed in colour intensity from normal wood and was divided into two groups: stained brown or dark brown. Decay of wood was not observed at the studied level of stem.

\section{Fungi isolation}

Sections of heartwood (5 $\mathrm{mm}$ long) showing brown and/or dark brown discolorations were surface sterilized with the use of $0.5 \%$ cupric chloride $(1 \mathrm{~min}$ ) and $70 \%$ alcohol (1 min). After rinsing in sterile water and dried in sterile filter paper, the sections were placed in Petri dishes containing 2\% (w/v) malt extract agar (MEA; Merck, Darmstadt, Germany). The dishes were incubated at room temperature $\left(22-25^{\circ} \mathrm{C}\right)$. Fragments of the medium with mycelium were transplanted onto fresh MEA immediately after the mycelium appeared, and the fungi were identified as soon as sporulation occurred.

Isolation frequency was defined as the percentage of isolates of individual species in relation to the total number of isolates obtained.

\section{Cellulase and pectinase assay}

Cellulolytic and pectolytic enzymes were studied by using the solid media, whose composition in $g$ per litre of distilled water was as follows:

1) for cellulase: medium with carboxymethylcellulose (CMC; Sigma-Aldrich Chemie, Germany, C - 5678, sodium salt, low viscosity) 10 , ammonium sulfate $0.5, \mathrm{~L}-$ asparagine 0.5 , potassium dihydrogen phosphate 1.0 , potassium chloride 0.5 , magnesium sulfate 0.2 , calcium chloride 0.1, yeast extract (Difco) 0.5 ( $\mathrm{pH} \mathrm{6.2;} \mathrm{Kjøller} \mathrm{and}$ Struwe 1980);

2) for pectinase: polygalacturonic acid (PA; Sigma-Aldrich Chemie, Germany P-3850, sodium salt) 5 or citrus pectin (CP; pectin from citrus fruit, Sigma-Aldrich Chemie, Germany, P 9135) 5, potassium sulfate 0.5 , potassium chloride 0.2 , calcium chloride 0.2 , magnesium sulfate 0.1 , ferrous chloride 0.01 ( $\mathrm{pH}$ 5; Kjøller and Struwe 1980).

Cellulose degradation was estimated by measuring the light zone around colonies after 1 month of incubation at $10^{\circ} \mathrm{C}$. Pectin degradation was estimated after 7 days of incubation at room temperature by covering the cultures with $1 \%$ ethylhexadecyldimethyl ammonium bromide (cetavlon; Sigma-Aldrich Chemie, Germany, 5335) for $30 \mathrm{~min}$.

Ten-day-old fungal cultures were transferred to Petri dishes containing the above-mentioned substrates. Three replicates were made for each isolate. The following scale was used to classify the reactions of the various fungal species to cellulase and pectinase: light zone 1-2 mm (slight reaction, +), light zone 3-4 mm (moderate reaction, ++ ), light zone 5-6 mm (strong reaction, +++ ).

\section{Bavendamm's test}

Bavendamm's test was used for estimation of phenoloxidase (laccase) production. Fungi were grown on a medium of the following composition: gallic acid (Ubichem, Hampshire, UK) or tannic acid (Sigma St Louis, MO, USA) 5 g, agar 20 g, malt extract (Merck, Darmstadt, Germany) 15 g per liter of distilled water (Kjøller and Struwe 1980; Rayner and Boddy 1988). Three isolates were tested for each fungus. Observations of the intensity of reaction and radial growth of mycelium were made after 7 days of incubation at room temperature (about $22^{\circ} \mathrm{C}$ ). The following scale was used to estimate the reactions of the various fungal species to gallic and tannic acid: - without brown discoloration (negative), + light brown to brown discoloration formed at the center of mycelium, ++ light to dark brown discoloration formed under mycelium but not extending to the mycelium margin, +++ light to dark brown discoloration extending a short distance (up to $1 \mathrm{~cm}$ ) beyond the mycelium margin, ++++ dark brown discoloration extending considerably beyond the mycelium margin $(1-2 \mathrm{~cm})$, +++++ dark brown discoloration forming a wide zone (over $2 \mathrm{~cm}$ ) around inoculum, without mycelium growth.

\section{Wood decomposition test}

An in vitro decomposition test was carried out to assess the effect of fungi dominating in one or both groups and differing in cellulase and pectinase activity: $C$. herbarum (positive cellulase and pectinase), $P$. melinii (positive cellulase and pectinase), $P$. jensenii (positive cellulase and pectinase), A. alternata (positive pectinase), Cryptosporiopsis sp. (positive pectinase), P. rubrum (positive pectinase), $C$. virescens (negative cellulase and pectinase), $P$. funiculosum (negative cellulase and pectinase) (Tables 1 and 2). The common original weight was determined for five wood blocks (ca. $0.5 \times 1 \mathrm{~cm}$ ) being one replicate for each species. Four replicates were used for each fungal species. The blocks were inserted into moist sand on Petri dishes (five blocks per one Petri dish) and autoclaved at $120^{\circ} \mathrm{C}$ for 30 min. Each block was inoculated with $0.2 \mathrm{ml}$ water suspension of mycelium of the fungi that were grown for 7 days on malt extract agar (MEA; Merck, Darmstadt, Germany). The suspensions exhibited the same density ( 0.04 at a wavelength of $520 \mathrm{~nm}$, Specord UV VIS Carl Zeiss, Jena, DDR). Control wood blocks were inoculated with $0.2 \mathrm{ml}$ of sterile water. After incubation for 2 months at ca. $23^{\circ} \mathrm{C}$, the wood blocks were removed and cleaned of adhering sand and mycelium. They were then dried at $105^{\circ} \mathrm{C}$ to constant weight. Weight losses were expressed as percentage of the original weight (Nilsson et al. 1989). The data were subjected to an analysis of variance and Tukey test (JMP version 4 - Academic AD00007160, USA 2001).

\section{Chemical analyses}

The milled wood samples of 11 trees showing discoloration and contiguous normal wood were analysed for total concentrations of the elements $\mathrm{N}, \mathrm{Ca}, \mathrm{Mg}, \mathrm{Mn}$ and $\mathrm{C}$.

Nitrogen was determined by a semi-microkjeldahl procedure after "wet" mineralization with sulfosalicylic acid. For analysis of $\mathrm{Ca}, \mathrm{Mg}, \mathrm{Mn}$ samples were digested in a 3:1 $(\mathrm{v} / \mathrm{v})$ mixture of nitric and perchloric acid. For $\mathrm{Ca}$ a flame photometric procedure was performed, whereas $\mathrm{Mg}$ and Mn were determined by atomic absorption spectrophotometry (Zeiss 3, Germany). Organic $\mathrm{C}$ was determined by 
TABLE 1. Fungi identified in the heartwood showing brown discoloration.

\begin{tabular}{|c|c|c|c|c|c|c|c|c|}
\hline \multirow{3}{*}{ Fungi } & \multirow{3}{*}{$\begin{array}{c}\text { Fungi } \\
\text { frequency } \\
(\%)\end{array}$} & \multicolumn{3}{|c|}{ Enzymes } & \multicolumn{4}{|c|}{ Bavendamm's test } \\
\hline & & \multicolumn{2}{|c|}{ Pectinase } & \multirow{2}{*}{$\frac{\text { Cellulase }}{\mathrm{CMC}}$} & \multicolumn{2}{|c|}{ Gallic acid } & \multicolumn{2}{|c|}{ Tannic acid } \\
\hline & & $\mathrm{CP}$ & PA & & Reaction & Growth $(\mathrm{mm})$ & Reaction & Growth $(\mathrm{mm})$ \\
\hline Acremonium sp. & 2.8 & - & - & - & - & 7.2 & - & 7.0 \\
\hline Alternaria alternata (Fr.) Keissler & 4.4 & + & + & - & + & 8.4 & + & 8.0 \\
\hline Aureobasidium sp. & 1.6 & - & - & - & - & - & - & - \\
\hline Chloridium virescens (Pers.: Fr.) W. Gams & 7.2 & - & - & - & - & 16.7 & - & $2.0 *$ \\
\hline Cladosporium herbarum (Pers.) Ling ex Gray & 17.6 & ++ & ++ & + & ++++ & $1.9 *$ & ++++ & $4.8^{*}$ \\
\hline C. macrocarpum Preuss & 2.8 & + & - & - & ++ & $2.0 *$ & ++ & $3.3 *$ \\
\hline Cladosporium sp. & 1.2 & - & - & - & ++++ & $2.7 *$ & ++++ & $5.7 *$ \\
\hline Coleophoma empetri (Rostr.) Petrak & 1.6 & - & - & - & - & 3.4 & - & 4.2 \\
\hline Diplodia sp. & 0.4 & ++ & ++ & - & - & 4.2 & - & 5.2 \\
\hline Endomyces sp. & 1.2 & - & - & ++ & +++ & $2.0 *$ & +++ & $2.0 *$ \\
\hline Epicoccum purpurascens Ehrnb. ex Schlecht. & 4.4 & + & + & - & + & 5.8 & + & 6.2 \\
\hline Gonytrichum caesium C.G. Nees et T.F.L. Nees & 7.2 & - & + & + & ++++ & $3.5^{*}$ & ++++ & $3.7^{*}$ \\
\hline Hormonema dematioides Lagerb. et Melin & 2.4 & - & ++ & - & - & 9.5 & - & 9.8 \\
\hline Hyphomycetes 1 & 1.6 & - & - & - & +++++ & $0.0^{*}$ & +++++ & $0.0 *$ \\
\hline Hyphomycetes 2 & 0.8 & - & - & - & +++++ & $0.0^{*}$ & +++++ & $0.0^{*}$ \\
\hline Mucor mucedo L. ex Fries & 1.6 & - & - & - & - & 9.2 & - & 9.9 \\
\hline Nodulisporium $\mathrm{sp}$ & 0.8 & - & - & - & - & 3.7 & +++++ & $0.0 *$ \\
\hline Ophiostoma quercus (Münch) H et P. Sydow & 1.6 & + & + & - & - & 6.5 & ++++ & $2.8^{*}$ \\
\hline Penicillium daleae Zaleski & 0.4 & + & + & - & - & 7.8 & - & 6.4 \\
\hline Penicillium granulatum Bain & 1.2 & - & - & + & - & $7.5 *$ & - & $7.5 *$ \\
\hline Penicillium jensenii Zaleski & 6.8 & - & + & + & - & 9.0 & - & 8.5 \\
\hline Penicillium purpurogenum Stoll & 0.4 & + & + & + & - & 7.1 & ++++ & $2.0 *$ \\
\hline Penicillium rubrum Stoll & 5.2 & + & + & - & - & 14.0 & - & 14.1 \\
\hline Penicillium sp. & 0.4 & - & - & - & - & 7.3 & - & 7.0 \\
\hline Phialocephala sp. & 1.6 & + & + & - & - & 11.6 & +++++ & $0.0 *$ \\
\hline Phialophora melinii (Nannf.) Cohant & 4.0 & +++ & + & +++ & + & 5.3 & ++ & 6.7 \\
\hline Phialophora sp. & 0.8 & ++ & ++ & - & - & 5.5 & - & 5.9 \\
\hline Sporothrix sp. & 0.8 & - & - & - & - & 6.4 & ++++ & $2.7 *$ \\
\hline Staphylotrichum sp. & 1.6 & - & + & + & - & 17.7 & - & 26.2 \\
\hline Thielaviopsis sp. & 1.6 & - & - & + & - & 32.3 & - & 24.8 \\
\hline Trichoderma sp. & 2.4 & - & + & - & - & 6.9 & - & 7.2 \\
\hline Non-sporulating & 5.6 & - & - & - & +++ & $4.7 *$ & - & 9.0 \\
\hline 2 & 2.4 & - & - & - & +++++ & $0.0 *$ & +++++ & $0.0 *$ \\
\hline 3 & 1.6 & - & - & - & +++++ & $0.0 *$ & +++++ & $0.0 *$ \\
\hline 4 & 0.8 & - & + & - & ++++ & $3.7 *$ & - & 6.2 \\
\hline 5 & 1.6 & - & + & - & + & 13.3 & +++ & $6.8^{*}$ \\
\hline Total number of inocula & 274 & & & & & & & \\
\hline Number of isolates examined $(100 \%)$ & 250 & & & & & & & \\
\hline
\end{tabular}

Radial growth (mm) on MEA (control): Acremonium sp. - 7.4, A. alternata - 9.6, Aureobasidium sp. - 3.1, Ch. virescens - 16.5, C. herbarum - 16.0, C. macrocarpum - 11.9, Cladosporium sp. - 12.2, C. empetri - 4.0, Diplodia sp. - 4.1, Endomycetes sp. - 5.5, E. purpurascens - 6.2, G. caesium 9.8, H. dematioides 10.0, Hyphomycetes 1 - 9.0, Hyphomycetes 2 - 8.0, M. mucedo - 9.6, Nodulisporium - 4.0, O. quercus - 6.9, P. daleae - 9.5, P. granulatum16.0, P. jensenii - 9.8, P. purpurogenum - 7.9, P. rubrum - 14.2, Penicillium sp. - 8.6, Phialocephala sp. - 12.0, Ph. melinii - 6.0, Penicillium sp. - 7.4, Phialophora sp. - 6.0, Sporothrix sp. - 10.1, Staphylotrichum sp. - 27.1, Thielaviopsis sp. - 13.0, Trichoderma sp. - 10.0, non-sporulating: 1 - 8.2, 2 - 9.1, $3-3.9,4-5.9,5-14.8$

* white field; the statistical differences (Student's test) in radial growth of mycelium; medium brownig occurred,

* in bold; the statistical differences (Student's test) in radial growth of mycelium without medium brownig,

in bold without asterix; no statistical differences (Student's test) in radial growth of mycelium; medium browning occurred.

the method of Lichterfeld in a modification of Alten. These analyses were carried out at the Department of Horticultural Plant Fertilization, University of Agriculture, Poznań. The data were subjected to an analysis of variance and Tukey test (JMP version 4 - Academic AD00007160, USA 2001).

\section{RESULTS}

\section{Fungi isolated from brown discoloration}

The 274 samples of brown-stained wood yielded 250 fungal isolates. This group was represented by 36 fungi, altho- ugh 16 of them could only be identified to species level. Within this group, five of the fungi differing in their culture morphology belonged to non-sporulating fungi. The most common fungus isolated from brown discoloration was $\mathrm{Cla}$ dosporium herbarum (over 40 isolates; 17.6\%). Relatively frequent, occurring in $10-18$ isolates, were: Gonytrichum caesium (7.2\%), Penicillium jensenii (6.8\%), non-sporulating no. 1 (5,6\%), P. rubrum (5.2\%), Alternaria alternata (4.4\%), Epicoccum purpurascens (4.4\%), and Phialophora melinii (4.0\%). Twenty-eight isolates occurred in fewer than 7 isolates $(3 \%)$. Within this subgroup of fungi isolated from brown discoloration, the total frequency of 6 species belonging to genus Penicillium were $14.4 \%$ (Table 1). 
TABLE 2. Fungi identified in the heartwood showing dark brown discoloration.

\begin{tabular}{|c|c|c|c|c|c|c|c|c|}
\hline \multirow{3}{*}{ Fungi } & \multirow{3}{*}{$\begin{array}{c}\text { Fungi } \\
\text { frequency } \\
(\%)\end{array}$} & \multicolumn{3}{|c|}{ Enzymes } & \multicolumn{4}{|c|}{ Bavendamm's test } \\
\hline & & \multicolumn{2}{|c|}{ Pectinase } & \multirow{2}{*}{$\frac{\text { Cellulase }}{\text { CMC }}$} & \multicolumn{2}{|c|}{ Gallic acid } & \multicolumn{2}{|c|}{ Tannic acid } \\
\hline & & $\mathrm{CP}$ & PA & & Reaction & Growth (mm) & Reaction & Growth $(\mathrm{mm})$ \\
\hline \multirow[t]{2}{*}{ Alternaria alternata (Fr.) Keissler } & 6.7 & + & + & - & + & 8.5 & + & 8.3 \\
\hline & 1.2 & + & ++ & - & - & 14.3 & - & 14.4 \\
\hline Chalara sp. & 0.8 & - & - & - & - & 7.5 & - & $5.3 *$ \\
\hline Chloridium virescens (Pers.: Fr.) W. Gams & 1.6 & - & - & - & - & 18.6 & - & $3.3 *$ \\
\hline Cladosporium herbarum (Pers.) Ling ex Gray & 2.4 & ++ & ++ & + & ++++ & $1.9^{*}$ & ++++ & $4.8^{*}$ \\
\hline Cryptosporiopsis sp. & 3.2 & + & + & - & - & 23.9 & - & 29.0 \\
\hline Gonytrichum caesium C.G. Nees et T.F.L. Nees & 3.2 & - & - & + & - & 9.9 & - & 8.5 \\
\hline Humicola sp. & 8.5 & - & + & - & ++ & $2.0 *$ & + & 6.9 \\
\hline Mortierella humilis Linn. et Gams & 8.5 & - & - & - & - & $13.4 *$ & - & $7.1^{*}$ \\
\hline Mortierella isabellina Oudem. & 2.8 & - & - & - & ++ & 28.0 & ++ & 25.0 \\
\hline Mortierella vinacea Dixon-Stewart & 0.8 & - & - & - & - & $15.3 *$ & - & 25.0 \\
\hline Ophiostoma quercus (Münch) H. et P. Sydow & 0.4 & - & - & - & - & 6.5 & ++++ & $2.8^{*}$ \\
\hline Paecilomyces variotii Bain & 1.2 & - & - & - & - & $7.0 *$ & - & 14.6 \\
\hline Penicillium frequentans Westling & 0.8 & + & + & + & - & 14.3 & - & 10.3 \\
\hline Penicillium funiculosum Thom & 9.4 & - & - & - & - & 10.3 & - & 10.0 \\
\hline Penicillium jensenii Zaleski & 7.2 & - & + & + & - & 9.0 & - & 8.5 \\
\hline Penicillium rubrum Stoll & 8.0 & + & + & - & - & 10.6 & - & 10.6 \\
\hline Penicillium steckii Zaleski & 0.8 & - & + & - & - & 7.5 & - & 6.8 \\
\hline Penicillium sp. & 1.6 & - & - & - & - & 7.8 & - & 6.8 \\
\hline Sordaria fimicola (Rob.) Ces. et de Not. & 3.2 & - & - & - & - & 11.9 & - & $6.5^{*}$ \\
\hline Trichothecium roseum (Pers.) Link ex Gray & 1.2 & - & - & - & - & $1.6^{*}$ & - & $1.0 *$ \\
\hline Trichoderma pseudokoningii Rifai & 1.6 & - & - & - & - & 15.6 & - & 10.3 \\
\hline Non-sporulating 1 & & & & & & & & \\
\hline Non-sporulating 1 & 0.8 & - & - & - & +++ & $4.7 *$ & +++ & $8.2 *$ \\
\hline+5 & 2.8 & - & - & + & +++ & 13.3 & +++ & 14.8 \\
\hline 6 & 0.8 & - & - & + & - & 10.2 & + & 6.7 \\
\hline 7 & 4.4 & - & - & - & - & 4.5 & - & 5.8 \\
\hline 8 & 2.4 & + & - & + & - & 4.7 & - & 3.4 \\
\hline 9 & 0.8 & + & + & - & - & 5.7 & - & 6.2 \\
\hline 10 (basidiomycetes) & 0.4 & - & - & - & +++ & $0.0 *$ & +++ & $0.0 *$ \\
\hline 11 & 12.6 & - & - & - & - & & & \\
\hline Total number of inocula & 204 & - & - & - & + & 18.9 & + & 14.8 \\
\hline Number of isolates examined $(100 \%)$ & 223 & & & & & & & \\
\hline
\end{tabular}

Radial growth (mm) on MEA (control): A. alternata - Table 1, A. niger-15.0, Chalara sp. - 10.1, Ch. virescens - Table 1, C. herbarum - Table 1, Cryptosporiopsis sp. -26.2, G. caesium-9.8, Humicola sp. - 8.3, M. humilis - 27.0, M. isabellina - 28.4, M. vinaceae - 25.0, O. quercus - Table 1, P. variotti - 15.0, P. frequentans - 15.2, P. funiculosum - 13.9, P. jensenii - Table 1, P. rubrum - Table 1, P. steckii - 9.8, S. fimicola - 13.7, T. roseum - 20.0, T. pseudokoningii - 16.5, non-sporulating: 1 - Table 1,5 - Table 1,7 - 8.8, 8 - 5.1, 9 - 5.5, 10 - 5.8, 11 - 4.9, 12 - 17.4.

* white field; the statistical differences (Student's test) in radial growth of mycelium; medium brownig occurred,

* in bold; the statistical differences (Student's test) in radial growth of mycelium without medium brownig,

in bold without asterix; no statistical differences (Student's test) in radial growth of mycelium; medium browning occurred.

Pectinase activity was shown by 17 sporulating and identified fungal species $(47.2 \%)$ and 2 non-sporulating fungi (5.5\%). Twelve fungi were active in medium containing $\mathrm{CP}$ and 18 in medium containing PA. The reaction classified as strong $(+++)$ was shown by $P$. melinii in medium with CP. The majority of studied species showed a low activity in $\mathrm{CP}$ as well as in PA (e.g. A. alternata, E. purpurascens) or in one of those substrates (e.g. G. caesium and $P$. jensenii) (Table 1).

Nine species $(25.0 \%)$ were able to produce cellulase in medium containing CMC. The most active (strong reaction) was $P$. melinii (Table 1).

Besides, 11 species $(30.5 \%)$ and 15 species (41.6\%) showed significant inhibition of radial growth of mycelium together with browning of medium containing gallic or tannic acid, respectively. The maximum inhibition related to the largest discoloured zone (+++++) of the medium was observed in Nodulisporium sp. (tannic acid), Phialocephala sp. (tannic acid), Hyphomycetes nos. 1 and 2 (both acids) and non-sporulating nos. 2 and 3 (both acids). A high phenoloxidase activity (++++) was exhibited also by $C$. herb $a$ rum, Cladosporium sp. and G. caesium in both used substrates; by non-sporulating no. 4 in gallic acid; and by Ophiostoma quercus, Penicillium purpurogenum, Sporothrix sp. in tannic acid. The radial growth of $C$. virescens and $P$. granulatum in the medium containing one of the two used acids was inhibited but no browning was noticed. The growth of Phialophora melinii was not inhibited in any of the two phenolic substrates, but in the case of tannic acid the medium browning zone $(++)$ was observed (Table 1).

\section{Fungi isolated from dark brown discoloration}

The 204 samples of dark-brown-stained wood yielded 223 fungal isolates. This group consisted of 30 fungi, however 18 of them could only be identified to species level. From dark-brown-stained wood, $26.6 \%$ of fungi were nonsporulating. The following fungi occurred most frequently (in over 15 isolates): non-sporulating no. 11 (12.6\%), $P$. fu- 
niculosum (9.4\%), Humicola sp. (8.5\%), Mortierella humilis $(8.5 \%), P$. rubrum $(8.0 \%)$, A. alternata $(6.7 \%)$ and $P$. jensenii $(7.2 \%)$. Twenty two fungi $(73.3 \%)$ occurred in fewer than 10 isolates $(4.4 \%)$. In this fungal group, Penicillium spp. were found in $27.8 \%$, and Mortierella spp. in $12.1 \%$ of total number of isolates (Table 2).

Pectinase activity was shown by 11 fungal species (36.6\%), of which 8 were active in medium containing CP and 10 in medium containing PA. The activity designated as moderate $(++)$ exhibited $C$. herbarum (in both substrates) and Aspergillus niger (in PA).

Cellulase activity was shown by 7 fungal species (23.3\%). A slight reaction (+) was observed in C. herbarum, G. caesium, $P$. frequentans, $P$. jensenii and non-sporulating nos. 5, 6 and 8 .

Besides, six fungal species $(20.0 \%)$ showed browning of medium with significant inhibition of radial growth of mycelium on medium containing gallic and/or tannic acid. In this group of fungi, the greatest inhibition related to the zone of extensive browning of medium (++++) was observed in $C$. herbarum (in both acids) and O. quercus (in tannic acid). The growth of some species in gallic or tannic acid was inhibited but no browning was noticed, e.g. $C$. virescens (tannic acid), M. humilis (both acids), M. vinacea (gallic acid), S. fimicola (tannic acid).

\section{Decomposition test}

In comparison with the control, only the species $C$. herbarum and $P$. melinii caused significant weight loss of inoculated wood blocks: $7.9 \%$ and $8.1 \%$, respectively (Table 3 ).

TABLE 3. Weight loss of wood caused by tested fungi.

\begin{tabular}{lc}
\hline Fungal species & Weight loss $(\%)$ \\
\hline Alternaria alternata & $4,4 \mathrm{~b}$ \\
Cladosporium herbarum & $7.9 \mathrm{a}$ \\
Chloridium virescens & $5.7 \mathrm{~b}$ \\
Cryptosporiopsis radicicola & $5,4 \mathrm{~b}$ \\
Penicillium funiculosum & $4,7 \mathrm{~b}$ \\
P. jensenii & $6.0 \mathrm{ab}$ \\
P.rubrum & $4.7 \mathrm{~b}$ \\
Phialophora melinii & $8,1 \mathrm{a}$ \\
Control & $4,5 \mathrm{~b}$
\end{tabular}

Means values marked with the same letter do not differ significantly $(\mathrm{P}<0.001 ;$ LS Means Differences Tukey HSD $)$

\section{Mineral concentrations}

The brown-discoloured wood contained significantly more $\mathrm{Ca}(0.51 \%), \mathrm{Mg}(0.022 \%)$, and $\mathrm{Mn}\left(57.4 \mathrm{mg} / \mathrm{kg}^{-1}\right)$ in comparison with dark-brown-stained wood and the control (Table 4).

\section{DISCUSSION}

The discoloration of heartwood in studied $Q$. robur trees can be a consequence of dieback of some aboveground organs and of wounds occurring on trunk. Heartwood contains enzyme systems that can function after injury (Shigo and Hillis 1973). Brown or dark brown heartwood discolorations, differing from the natural colour, were observed on samples obtained from trees by use of a Pressler borer. Hence, in this work it was impossible to observe the co-
TABLE 4. Concentrations of minerals in trunk heartwood of $Q$. robur.

\begin{tabular}{lccc}
\hline \multirow{2}{*}{ Minerals } & \multicolumn{2}{c}{ Heartwood discoloration } & $\begin{array}{c}\text { Normal heartwood } \\
\text { (control) }\end{array}$ \\
\cline { 2 - 3 }$\% \mathrm{~N}$ & Brown & Dark brown & $0.39 \mathrm{a}$ \\
$\% \mathrm{C}$ & $0.45 \mathrm{a}$ & $0.36 \mathrm{a}$ & $50.8 \mathrm{a}$ \\
$\% \mathrm{Ca}$ & $43.9 \mathrm{a}$ & $45.7 \mathrm{a}$ & $0.22 \mathrm{~b}$ \\
$\% \mathrm{Mg}$ & $0.51 \mathrm{a}$ & $0.25 \mathrm{~b}$ & $0.005 \mathrm{~b}$ \\
$\mathrm{mg} \mathrm{Mn} \mathrm{kg}^{-1}$ & $0.022 \mathrm{a}$ & $0.009 \mathrm{~b}$ & $40.4 \mathrm{~b}$ \\
\hline
\end{tabular}

Means values marked with the same letter within lines do not differ significantly ( $\mathrm{P}=0.2$ for $\mathrm{N} ; \mathrm{P}=0.06$ for $\mathrm{C} ; \mathrm{P}=0.03$ for $\mathrm{Ca}, \mathrm{P}=0.04$ for $\mathrm{Mg}$; $\% \mathrm{P}=0.03$ for Mn; PLS Means Differences Tukey HSD)

lumns of discoloration extending from dead branches and wounds, or the discoloration patterns on stem in cross section. The trees were not felled, considering their age and special protection.

The accumulation of minerals in trunk wood depends usually on stages of wood decomposition (e.g. Shigo and Hillis 1973; Krankina et al. 1999). In studied Q. robur trees the levels of $\mathrm{Ca}, \mathrm{Mg}$ and $\mathrm{Mn}$ in brown-stained heartwood were statistically higher than in normal or dark-brown-stained wood. In the case of Acer saccharum, Shortle and Shigo (1973) found the highest concentration of Mn, responsible for detoxification of phenolic compounds (Shortle et al. 1971), in the interface between decayed wood and discoloured wood. The concentrations of the minerals studied in that paper were statistically higher in heartwood of old $Q$. robur trees showing decay caused by Phellinus igniarius $(\mathrm{P})$ and Fomes fomentarius (F), as compared with normal and both types of discoloured wood in this study $(\% \mathrm{~N}: 1.30 \mathrm{P}, 1.65$ F;\%Ca: 2.12 P, 1.72 F; \%Mg: $0.069-\mathrm{P}, 0.13-\mathrm{F}, \mathrm{Mn} \mathrm{kg}^{-1}$ : 518.4 P, 299.5 F) (Przybył, unpublished data).

The brown-stained heartwood was a more active site, considering the number of fungal species isolated and their ability to produce enzymes, in comparison with the darkbrown-stained wood. In the brown-stained heartwood, the total number of fungi that are able to detoxify the phenolic substances and degrade wood by production of enzymes (cellulase and pectinase) were higher than in dark-brownstained wood.

Nine species (e.g. A. alternata, C. herbarum, O. quercus, $P$. jensenii, $P$. rubrum) were common to both types of discolorations, but they differed in frequency $(\%)$. C. herbarum was the most common fungus isolated from the brown discoloured heartwood. The most known soft rot fungus $P$. melinii (Rayner and Boddy 1988) was isolated only from brown discoloration. This fungus was commonly found in discoloured wood of other tree species, e.g. sweetgum and yellow-poplar, and belonged to persistent colonizers, which grow at gallic acid levels inhibitory to decay fungi and persist in wood by utilizing some cell wall substrates (Shortle et Cowling 1978). Among the fungi that dominated in both types of discoloration, used in the wood decomposition test, only $P$. melinii and $C$. herbarum caused significant weight loss of inoculated heartwood blocks in comparison with the control. Some nonhymenomycetous fungi, e.g. P. melinii, P. bubaki, and Cladosporium sp., were found to cause significant weight loss due to wood decomposition in other tress, e.g. sweetgum wood (Shortle and Cowling 1978). The less enzymatically active Penicillium spp. and Mortierella spp. were isolated more frequently 
from dark-brown-stained wood than from brown-stained wood. From dark-brown-stained wood, the basidiomycete was also isolated (at a frequency of $0.4 \%$ ). Although any clamp-connexions were not observed in non-sporulating fungi occurring in brown heartwood, it is plausible that certain non-sporulating fungi could be involved in Basidiomycetes.

Generally, these investigations showed that the brownstained heartwood contained statistically more $\mathrm{Ca}, \mathrm{Mg}$ and $\mathrm{Mn}$ as well as a higher number of enzymatically active fungi than dark-brown-stained wood. This brown-stained trunk heartwood of old $Q$. robur trees could be regarded as a more advanced stage in discoloration and maybe in decomposition process because: (1) the accumulation of minerals in stem wood depends usually on stages of wood decomposition and (2) in agreement with the theory of succession (e.g. Shigo 1972), the pioneer fungi that are not able to produce enzymes followed by fungi active enzymatically.

Further research should be concerned with the identification of non-sporulating fungi in comparison to the commonly known fungi causing heartwood decay of oaks and their ability to decompose wood.

\section{ACKNOWLEDGEMENTS}

This work was carried out within grant No. 2 P04G 007 26. The author thanks Dr. K. Ufnalski and M. Ratajczak for their help in obtainment of heartwood samples and $\mathrm{M}$. Wójkiewicz for technical assistance in laboratory work.

\section{LITERATURE CITED}

ARNOLD G.R.W., GRAMSS G. 1992. The role of Acremonium butyri in healing wounds of standing timber. Nova Hedwigia 55: 419-427.

DUJESIEFKEN D., STOBBE H., ECKTEIN D. 1998. Langzeitwirkungen von Astungen im Holz von Linde und Rosskastanie. Forstwissenschaft. Centralblatt. 117: 305-315.

FUKASAWA Y., TAKASHI O., TAKEDA H. 2005. Small-scale variation in chemical property within logs of Japanese beech in relation to spatial distribution and decay ability of fungi. Mycoscience 46: 209-214.

GROSCLAUDE C. 1993. Pathologié des blessures mettant a nu le bois chez les vegetaux ligneux. Agronomie 13: 441-456.

HALLAKSELA A.M., NIEMISTÖ P. 1998. Stem discoloration of planted silver birch. Scan. J. For. Res. 13: 169-176.

HON D.N.S., FEIST W.C. 1986. Weathering characteristics of hardwood surface. Wood Sci. Technol. 20: 169-183.
KASPRZAK K. 2001. Ochrona pomników przyrody - zasady postępowania administracyjnego. Przegląd Komunalny (dodatek branżowy) 55, 3. Poznań. (in Polish)

KJØLLER A., STRUWE S. 1980. Microfungi of decomposing red alder leaves and their substrate utilization. Soil Biol. Biochem. 12: 425-431.

KRANKINA O.N., HARMON M.E., GRIAZKIN A.V. 1999. Nutrient stores and dynamics of woody detritus in boreal forest: modeling potential implications at the stand level. Can. J. For. Res. 13: 169-176.

LILJA A., HEIKKILÄ R. 1995. Discoloration of birch trees after wounding or breakage. Norw. For. Res. Inst. Res. Pap. 4: 30-32.

NILSSON T., DANIEL G., KIRK T.K., OBST J.R. 1989. Chemistry and microscopy of wood decay by some higher Ascomycetes. Holsforschung 43: 11-18.

PENNINCKX V., GLINEUR S., GRUBER W., HAERAUTS J., MEERTS P. 2001. Radial variations in wood mineral element concentrations: a comparison of beech and pedunculate oak from the Belgian Ardennes. Ann. For. Sci. 58: 253-260.

PRZYBYŁ K. 2001. Fungi and bacteria associated with the wet and brown wood in trunk of Betula pendula trees. Acta Soc. Bot. Pol. 70: 113-117.

PRZYBYŁ K., MAŃKA M. 2000. Nutrient content in prematurely yellowed leaves and in brown discoloured trunk wood of Betula pendula trees. Phytopathol. Pol. 19: 97-106.

RAYNER A.D.M., BODDY L. 1988. Fungal decomposition of wood: its biology and ecology, Wiley, Chichester.

SHIGO A.L. 1972. Successions of microorganisms and patterns of discoloration and decay after wounding in red oak an white oak. Phytopathology 62: 256-259.

SHIGO A.L., SHARON F.M. 1970. Mapping columns of discolored and decayed tissue in sugar maple, Acer saccharum. Phytopathology 60: 232-237.

SHIGO A.L., HILLIS W.E. 1973. Heartwood, discolored wood and microorganisms in living trees. Annu. Rev. Phytopathol. 11: $197-222$.

SHORTLE W.C. 1979. Compartmentalization of decay in red maple and hybrid poplar trees. Phytopathology 69: 410-413.

SHORTLE W.C., TATTAR T.A., RICH A.E. 1971. Effects of some phenolic compounds on the growth of Phialophora melinii and Fomes connatus. Phytopathology 61: 552-555.

SHORTLE W.C., SHIGO A.L. 1973. Concentrations of manganese and microorganisms in discolored and decayed wood in sugar maple. Can. J. For. Res. 3, 354-358.

SHORTLE W.C., COWLING E.B. 1978. Interaction of live sapwood and fungi commonly found in discolored and decayed wood. Phytopathology 68: 617-623.

TATTAR T.A., SHORTLE W.C., RICH A.E. 1971. Sequence of microorganisms and changes in constituents associated with discoloration and decay of sugar maples infected with Fomes connatus. Phytopathology 61: 556-558. 